\title{
Sade para além da cruz e da espada
}

\author{
Sade Beyond the Cross and the Sword
}

\author{
Francisco Verardi Bocca \\ Professor titular da Escola de Humanidades e Educação \\ Pontificia Universidade Católica do Paraná [PUCPR]
}

\section{RESUMO}

Também em relação à política Sade foi um enigma, particularmente porque nunca foi sincero sobre ela. Além disso, consideraçóes imprecisas de biógrafos e comentadores contribuem. Esclarecê-lo demanda uma investigação atenta, que espero ter realizado nas obras Sade contre l'Etre Suprême (I793) e La philosophie dans le boudoir (I795), redigidas durante o período de instalação da primeira República francesa. Por meio delas revelo Sade táo pouco monarquista quanto republicano. Em acréscimo, em La nouvelle Iustine (I797) e Histoire de Juliette (I797), revelo sua filosofia política construída pela condução do materialismo francês levado às últimas consequências, que ilustro pela noção de Orgia.

\section{PALAVRAS-CHAVE}

Sade; Política; República; Monarquia; Orgia.

\begin{abstract}
Sade has also been an enigma in relation to politics, particularly because he has never been sincere about it. Considerations that are not always precise made by biographers and commentators also contribute to it. Clarifying it calls for a careful investigation, which I hope to have carried out with the works Sade contre l'Être Suprême (1793) and La philosophie dans le boudoir (1795), written during the period of installation of the first French Republic. Through them I reveal Sade as little Monarchist as Republican. Moreover, with La nouvelle Justine (I797) and Histoire de Juliette (1797), I reveal his political philosophy built on the conduction of the materialistic theses taken to the ultimate consequences, which I illustrate with the notion of Orgy.
\end{abstract}

\section{KEY WORDS}

Sade; Politics; Republic; Monarchy; Orgy. 
Encore un effort!', é uma conhecida palavra de ordem utilizada por Marquês de Sade em pelo menos duas ocasiôes: em I793, na carta intitulada Sade contre l'Etre Suprême ${ }^{1}$ e em I795, na obra La philosophie dans le boudoir. Ambas expressam à primeira vista intençóes semelhantes, mas apenas à primeira vista, pois foram redigidas em diferentes circunstâncias políticas da revoluçáo francesa, o primeiro e o terceiro ano do chamado regime da Convenção que instituiu a primeira República francesa. Também foram redigidas a partir de diferentes estratégias de atuação e expectativa política de Sade.

Na primeira obra, valendo-se da expressão, Sade conclamou o povo a repudiar a abolição da realeza, a proclamação da primeira República, mas especialmente a resistir às medidas que instituíram o culto ao Ser supremo e aos seus corolários como a imortalidade da alma e a virtude como essência da nova sociedade francesa. Também repudiou o Iluminismo por considerá-lo um culto à razão travestido de obscurantismo e de concessão à burguesia conservadora. Já na segunda obra conclamou os franceses republicanos, tanto radicais como moderados, a se unirem contra os monarquistas, mas mais uma vez contra o fanatismo dos católicos seus aliados. Em suma, criticou a Convenção pela concessão aos valores religiosos: "Não, não queremos mais um deus que perturba a natureza, que é o pai da confusão, que move o homem no instante em que ele se entrega aos horrores. Um deus como este nos faz tremer de indignação e nós o relegamos para sempre ao esquecimento, de onde o infame Robespierre quis tirá-lo" (Sade, I795, p. 195). No entanto, desta vez recorreu às mesmas Luzes a fim de evitar um obscurantismo ainda maior. Em vista disto, pode-se perguntar se de fato se trata de um Sade monarquista que em três anos mudou de lado e aderiu à República. Pode ser que sim, mas pode também ser que não. $\mathrm{O}$ fato é que talvez não seja este o caso. Talvez esta polarização apenas reflita uma má colocaçáo do problema acerca da posição política de Sade. Para efeitos de recolocá-la, começo por considerar que Sade não foi republicano nem monarquista, o que me traz o encargo de identificar, antes de tudo, qual seria sua filosofia política. Filosofia que, antecipo, consistiu num acontecimento peculiar do século XVIII francês. Isto porque, segundo entendo, o esforço que ele mais de uma vez recomendou aos franceses justificava-se em relação à sua concepção política-filosófica e não às já existentes, ou seja, justifica-se como esforço realizado pelo libertino a fim de impulsionar a verdadeira revolução que ele próprio espera ver realizada.

No mesmo período em que redigiu a carta ao cardeal de Bernis, Sade também redigiu outros textos políticos, pelos quais foi acusado de traição e detido ${ }^{2}$, além de pelos outros motivos que todos conhecem. Intitulada Sade contre l'Être Suprême, nela mostrou antipatia pelos dois regimes, como confidenciou ao interlocutor: "eles

1 Segundo Philippe Sollers (1996), trata-se de uma carta de 07 de dezembro de 1793 endereçada ao cardeal de Bernis, exilado em Roma e morto no ano seguinte.

2 Sollers (1996) informa que Sade foi preso um dia após a redação (o7 de dezembro de 1793) desta carta, o que deu início à série de prisóes a que foi submetido sob o regime do Terror. 
se equivalem. $\mathrm{O}$ fanatismo os reúne na trindade eterna da burrice, da ignorância e do preconceito" (Sade, I793, p. 92). Para continuar adiante: "de minha parte, não quero rei nem república; não quero nação; também não quero Ser em supremo! Não tenho a intenção de aplaudir este carnaval! Aplaudir este Jeová de papelão, de som ou, na verdade, de aço! Esta apologia da alma de ratos!" (ibid., p. IO4). Enfatizando que o Ser Supremo "é verdadeiramente um deus dos mortos. O antigo era semelhante, mas pelo menos fingia ser o deus dos vivos" (ibid., p. IO5).

Como se vê, condenou enfaticamente o restabelecimento do que chamou quimera deífica, uma nova religiáo que combateu energicamente e que esperava que não se concretizasse, da qual não foi apenas um mero crítico. Assumindo posição, declarou que: "Você conhece meu lema: desordem, beleza, luxo, frenesi, volúpia. E ainda, se o ateísmo precisa de mártires, meu sangue está disponível” (ibid., p. 79). Lemas que representam, como admitiu, seu "verdadeiro pensamento" (ibid., p. Io7). Além disso, confessando sua insinceridade, admitiu ter naquele momento se cumpliciado ao movimento republicano, mas apenas de maneira simulada a fim de preservar sua liberdade e sua vida. Nesta condiçáo ocupou, em I793, o cargo de secretário da Section des piques, à qual pertenceu Robespierre. Certamente um dado biográfico que induz a equívocos sobre sua filiação política. Equívoco que pode ser desfeito a partir da consideraçáo de que, como lembra Terrasse, Sade foi "um escritor que teve a honra de conhecer as prisôes do Antigo regime assim como as do regime da liberdade" (Terrasse, 1989, p. 42).

De fato, sua consciência de que uma crença e uma política abominável estavam sendo substituídas por outras equivalentes se mostrou bastante clara na ocasiáo. Interrogou se não "era necessário quebrar os altares da superstiçáo e do fanatismo para reconstruir, ao inverso, esse culto grosseiro? (Sade, I793, p. 72). Até porque, como lhe parecia, "o costume muda, mas a alma de lama permanece idêntica" (ibid., p. 77). De argumentos como este já se pode vislumbrar a justificativa de sua insistência pelo esforço a mais, esforço a fim de evitar não apenas a estagnação do projeto revolucionário, mas o retrocesso de conquistas sociais, morais e políticas que profeticamente antevia. Em favor deste argumento lembro do i8 brumário de 1799 de Napoleão, além da restauração da monarquia em I8I4. Na verdade, Sade manifestou uma previsão dos fatos políticos futuros justificada na consideraçáo de que a farsa revolucionária apenas se empenhava em trocar as vestimentas de uma marionete. Farsa construída a partir de um argumento mais sofisticado, o de que a revolução trazia consigo o que chamou de História, ou seja, a noção de progresso táo cara ao Iluminismo francês e em geral. Trata-se de uma ilusão que entendia ter por finalidade servir, de modo disfarçado, ao conservadorismo, já que todo estágio alcançado, quando consolidado, era sempre proclamado como "o fim da história, e é precisamente a isto que assistimos nos dias de hoje” (Sade, I793, p. 78), concluiu. Com tom profético interrogou seu interlocutor se não estariam trocando um tirano por outro pior: "Não vamos trocar um tirano por outro pior? E por que não, daqui 
a pouco, um ditador que assumisse o título de mufti ou, ainda mais engraçado, o de imperador? (ibid.). Deste modo, para ele estavam as Luzes preparando as trevas. Como veremos, sua própria noção de história sustentava não o progresso como finalidade, mas o fim da história, por conta do que o futuro deixa de ter futuro.

$\mathrm{Na}$ verdade, a nova como a velha ideologia portavam uma concepção de homem radicalmente distinta da sua, esta sim construída no bojo do empirismo e do materialismo filosófico. Para Sade, ambas ideologias sustentavam uma concepção de homem distante de sua organização natural ${ }^{3}$, além de visarem sua manipulação, quer dizer, recusá-la. Como disse, "O que vemos formar-se atualmente? Corpos cortados, privados de seu valor, desinfetados, saudáveis, regularmente retalhados sem o menor sinal de lubricidade aparente" (Ibid., p. 73), ou seja, desprovido de suas inclinaçóes naturais. Assim, a revolução apenas eliminava o súdito enquanto dava nascimento ao cidadão artificializado, ainda mal definido entre o burguês/girondino e o sanscullotes/jacobino.

Quanto à sua própria concepção política e de homem, que recusava tanto o súdito quanto o cidadão, admitiu: "Meus desejos são sempre vivos, variados, incansáveis, continuamente renovados pela imaginação. O pensamento que eu tenho disso é o próprio pensamento. Não o sacrificarei no altar do último fantoche" (ibid., p. 79). Como se vê, inspirado até certo ponto em La Mettrie, visava o resgate do homem natural atribuindo à razão e à imaginação, enquanto sua faculdade principal, a tarefa de em lugar de estabelecer controle da sensibilidade e diálogo com outros homens, apenas atender às suas inclinaçóes e realizar os desejos que elas ensejam.

Para ele, o próprio Terror revelava o mais íntimo da vida passional do homem: "Se a intenção fosse pôr a nu o nó das paixôes humanas, que encerram a aniquilação de todos por todos, o sucesso não teria sido maior" (ibid., p. 8I). Ele, em si mesmo, seria uma decorrência da espontaneidade da vida passional humana e, portanto, não deveria ser interrompido. Sua sugestão foi a de adicionar nele um pouco de invenção e de pimenta. Sugeriu que o Terror, com seus crimes e vícios, fosse justificado por uma filosofia da natureza humana e não condenado por um moralismo conservador e hipócrita. Até porque, a própria virtude recomendada pela revoluçáo tinha por meta extinguir sua própria agressividade, conduzir toda paixão à morte. Refletiu, "a ponto de se perguntar se a intençáo profunda de todo este abatedouro patriótico não seria conduzir à morte contra os prazeres de um século inteiro, aniquilando-o com uma punição na medida de suas devassidóes e de seus excessos” (ibid., p. 90).

\footnotetext{
3 Segundo Clara de Castro (20I7, p. 29) há pelo menos cinco sentidos diferentes para o termo organizaçáo utilizado por Sade: (I) um sinônimo de máquina cartesiana, (2) uma disposiçáo específica da matéria que possibilita vida e pensamento, (3) a forma específica com que a matéria viva se dispóe num todo contínuo (uma máquina com sentimento e movimento), (4) um mero arranjo geométrico de partículas independente da vida, (5) uma propriedade da matéria. Segundo ela, em Sade ele é empregado com certa ambiguidade nos diferentes discursos dos libertinos.
} 
Nestes termos, a virtude e a restauração do Ser Supremo somadas à crença na imortalidade da alma sustentavam a possibilidade de criação de corpos dóceis, sem memória, sem história:

Em suma, o Ser supremo quer selecionar seus corpos e tomá-los, por assim dizer, pela base. É uma experiência de triagem. Talvez um dia ele chegue a inventá-los inteiramente, a produzi-los sem memória, sem passado, incultos, obedecendo imediatamente à sua voz de ferro (Sade, 1793, p. 93).

Finalmente, posso dizer que foi da recusa e superaçáo deste e de todo horizonte limitador e manipulador da natureza humana que Sade se ocupou verdadeiramente enquanto simulava ora críticas ora apoios aos regimes em contenda. Para isto, considerou que a garantia do esforço a mais estaria nas letras e nas práticas libertinas que são poderosas, pois como disse, "a chama da filosofia se acenderá sempre ante a chama do coito, ela não se apagará nos templos, ainda que mil seres supremos se agitem para lhe sufocar a centelha" (ibid., p. IIO). Já a crença na imortalidade da alma foi combatida com recurso a um argumento emprestado de La Mettrie (Traité de l'âme, cap. XXVII), sustentando a finitude do corpo humano e a mente em lugar de alma. Denunciou que a imposiçáo do dogma da imortalidade da alma estava associada ao contínuo assassinato de corpos e ao desprestígio de sua sensibilidade: "A alma imortal e ilusória alimentando-se de corpos" (Sade, I793, p. 9I). Assim, foi à presença dominadora do Ser Supremo, à virtude, à imortalidade da alma e à anulação das potências do corpo que Sade contrapôs sua filosofia que não era nem a da revoluçáo, nem a do velho regime. Uma filosofia que expôs a natureza humana em sua nervura especial, pois como disse, "em mim, não tenho receio de dizer, os homens continuariam a se agitar em seu lodaçal de paixôes e daí tirar prazer, sem se dar conta disso" (ibid., p. 99). Sem qualquer modéstia declarou: "Eu penetrei o segredo" (ibid.). Uma filosofia que ainda revela seu destino na Terra: "Meu corpo não é nada, cairá onde o acaso quiser" (ibid., p. Io8). Em nome do homem natural e sua condição de existência denunciou toda forma conhecida de civilização como hipócrita e sua conservação como infrutífera, pois, como disse, querer conservá-la "é conhecer mal os homens pensar que eles buscam o objetivo que confessam. Eles dizem branco e pensam preto. Sim, quando é não. Pureza e eis o vício. Virtude e a corrupção aumenta" (ibid., p. 75).

Intitulado Français, encore un effort si vous voulez être républicains, serviu como instrumento para Sade manifestar uma posição política que até certo ponto pareceu ser a de apoio à República contra a monarquia. De fato, sem vacilo se posicionou contra os esforços reacionários e conservadores, especialmente após o assassinato de Robespierre e ao conflito generalizado que se sucedeu, manifestando seu desprezo: "veremos se não são todos inimigos irreconciliáveis do sistema atual; veremos se não é entre eles que se encontra toda esta casta tão justamente desprezada de realistas e 
aristocratas" (Sade, 1795, p. 19I). Identificando o inimigo comum, convocou os franceses a "Mais um esforço! Já que trabalhais para destruir todos os preconceitos, não deixais subsistir nenhum, se um apenas basta para trazer todos de volta" (ibid., p. 194). Para continuar adiante: "tenhamos boas leis, e passaremos bem sem a religião" (ibid., p. 195). Em suma, trata-se de declaraçóes solidárias, mas aos republicanos ateus, ao mesmo tempo em que critica o revisionismo religioso de Robespierre. ${ }^{4}$

Este aparente imbróglio pode ser desfeito mediante o esclarecimento acerca do tipo de leis e costumes que Sade recomendou. Certamente não se trata das leis de privilégio monarquistas nem das leis republicanas que concedia direitos de cidadania aos homens igualando-os. Por isto não se solidarizou com a constituição republicana que acabou não sendo promulgada. De fato, sua recomendação se apoiava nas leis da natureza que deveriam ser reconhecidas e respeitadas, pois como disse "estas leis são tão sensatas quanto simples; [...] são escritas no coração de todos os homens, basta interrogar seu coraçáo para desvendar seu impulso" (ibid., p. 199). Nestes termos, não resta dúvida de que a educação nacional que conclamou deveria se inspirar na autoridade da natureza, no respeito às inclinaçóes que ela dota os homens e nos desejos que ensejam delas.

Um processo educativo revolucionário desta monta só poderia começar pelo combate à religiáo que consistia de maneira resiliente no berço do despotismo tanto monarquista como republicano. Por isto, sua derrocada suscitaria outra concepção de homem, de moral e, sobretudo, de política. Para tanto, sua estratégia consistiu de início na aniquilaçáo da ideia de Deus e de criação, colocando em seu lugar a de natureza e suas determinaçóes. Mostrou estar convencido de que "a religiáo deve apoiar-se sobre a moral, e não a moral sobre a religião, é preciso uma moral que se dirija aos costumes [...] mantendo-a sempre à altura da liberdade que constitui hoje seu único ídolo" (ibid., p. I88). De modo que nossas crenças, costumes e leis passem a se orientar pela nossa própria moral, a moral dos homens fortes produzidos pela natureza. Neste caso, uma moral natural que contempla o roubo, a prostituição, o incesto, o homicídio, o infanticídio, a mentira etc.

Para tanto, como dito acima, propôs uma educação nacional de conversão de valores tanto monarquistas como republicanos, pois só assim "algumas virtudes ao menos brotarão deste culto, enquanto só nascem crimes daquele que tivemos a fraqueza de professar" (Sade, I795, p. 196). Com este ânimo conclamou os verdadeiros revolucionários a corrigirem seus erros do passado, mas sobretudo a prevenirem os futuros, uma vez que "a revolução foi preparada pela estupidez de um povo outra

\footnotetext{
4 Terrasse esclarece que "em um relatório apresentado à Convenção, reunião do I8º Ano Floreal II, Robespierre denunciou o ateísmo como "ligado a um sistema de conspiraçáo contra a República", invocou Licurgo, Sólon e até mesmo Sócrates para justificar a restauração da garantia religiosa. Para o culto do Ser Supremo instituído pelo "infame Robespierre", Sade se opóe à utilidade que teria em seus olhos a restauração dos deuses pagáos: as estátuas de Vênus, Marte e Minerva encontram lugar ao lado da estátua da Liberdade numa utopia política que assume as últimas consequências da morte de Deus e repele as consolaçóes hipócritas” (Terrasse 1989, p. 48).
} 
vez escravizado, e sem o menor obstáculo. Como poderíamos desconfiar que a obra da filosofia seria mais temível do que a do despotismo?" (ibid., p. 197). Com tal interrogação, mesmo criticando-a, elevou a razão à condição de instrumento de crítica e de acesso à verdade, conferindo à razão um papel esclarecedor e, por isto, criador da possiblidade de levantar o véu encobridor da condição humana natural. Desta forma, se o revolucionário encontra limitaçóes que náo lhe permite avançar, cabe ao libertino socorrê-lo, cumprindo a tarefa de superar, destruindo, as ideologias políticas e as crenças religiosas da época.

Assim, o panfleto pode ser considerado como parte de uma estratégia de denúncia e de encorajamento a mudanças de costumes, além de transformação social, tudo como efeito de um esforço incessantemente realizado. Fica assim evidente que, em seu ponto de vista, o verdadeiro combate requeria um esforço suplementar para uma efetiva e permanente revolução. Quem sabe até acreditasse de fato faltar pouco para seu êxito, a deposição definitiva do cetro e do incensório? Deposição seguida da destruição contínua dos preconceitos, da moralidade, de si mesmo e do outro como semelhante e de tudo isto como destinado, como veremos, a um fim inevitável determinado pela própria natureza. Ponto de vista que revela a verdadeira posição política de Sade, além de sua filosofia. Nem República, nem Monarquia, já fica cada vez mais evidente. Mas qual filosofia e qual política? Por enquanto, ambas baseadas na verdadeira educação nacional expurgada de religião, embora ainda não saibamos em detalhe todo seu caráter e extensão.

Pois bem, recusada toda forma de religiosidade comum a ambos regimes, Sade avançou na crítica aos costumes franceses avaliando-os em relação às leis que ele próprio esperava fossem promulgadas por um novo e revolucionário regime. Evidentemente já não se trata de um regime resultante da contenda entre republicanos e realistas. Restava refletir sobre a medida e a regulamentação das açóes humanas em geral, mas sobretudo sobre seu fundamento. Sobre isto Sade declarou:

Porque a natureza nos ditando igualmente os vícios e as virtudes, em razão de nossa organização, ou mais filosoficamente falando, em razão da necessidade que ela tem de ambos, ela nos inspira a uma medida muito incerta quanto a discernir com precisão o que é o bem e o que é o mal (Sade, I795, p. 204).

No entanto, não se trata de um simples relativismo moral que, por ventura, obsta a autoridade da natureza. Ao contrário, como disse adiante, "seu melhor órgão (sua voz) deve dirigir todas nossas açóes" (ibid., p. 207). Além disso, reconhecendo o caráter de singularidade e exceção que toda uma tradição filosófica empirista-materialista atribuiu ao homem, Sade declarou que "seria um evidente absurdo querer prescrever (aos homens) leis universais" (ibid., p. 208). Assim, deslocou o fundamento moral dos costumes da lei universal, que orienta e constrange, para a ordem do Direito natural, que concede e estimula o gozo dos desejos. Isto porque não lhe 
restava dúvida de que a universalidade da lei, que supóe homens igualizados, despreza justamente o caráter desigual dos homens desconsiderando sua peculiar organização natural. Neste caso, seja republicana ou monarquista, a lei, na impossibilidade de haver uma para cada homem, única circunstância em que não ultrajaria a natureza, estaria invariavelmente em oposiçáo à natureza. Foi, por fim, em nome do materialismo ateu que ofereceu suas sugestóes na esperança de ter pelo menos parte de suas expectativas atendidas por ocasião do "novo código que estamos preparando" (ibid., p. 205).

Neste código, a calúnia, o roubo e o assassinado seriam justificados pelos seus aspectos positivos. Para ficar em um exemplo, argumentou que "o roubo, cujo efeito é nivelar as riquezas, é um grande mal num governo cujo objetivo é a igualdade. Não, sem dúvida, porque, se de um lado ele mantém a igualdade, de outro mostra como se deve conservar os bens" (ibid., p. 213). Sugestáo que ecoa sua crítica à noçáo de pacto social, uma vez que consiste em que, a fim de se tornar cidadão, cada homem renuncie ao direito natural a todas as coisas, além de suas propriedades para assegurar e manter o que pode, ou espera, conservar. Nestes termos, o roubo só poderia ser criminalizado em função do injusto respeito à propriedade alheia.

Para além dela, quanto a si mesmo, o homem "segue o primeiro e o mais sábio dos movimentos da natureza, aquele de conservar sua própria existência, não importando à custa de quem" (ibid., p. 215). Ecoando as teses de Hobbes em Do cidadão, declarou que "todos os homens nascem livres, todos são iguais em direito" (ibid., p. 22I). Assim, sempre sob o primado deste direito, as leis que esperava de uma verdadeira República teriam a função, náo de obstaculizar (a partir do que se afasta de Hobbes), mas de sempre oportunizar o direito incontestável concedido pela natureza de realizar livremente os desejos humanos e conceder-lhes toda posse de objetos necessária para suas realizaçóes.

Para ele, o verdadeiro republicano, no exercício do seu Direito natural, náo apenas calunia, mente, rouba e assassina, mas também pratica toda forma de libertinagem, como prostituição, adultério, incesto, estupro e sodomia. O faz sempre visando a realização de seus desejos e, por consequência, demanda uma sociedade sob um governo pautado por este espírito. ${ }^{5}$ De modo que uma condição de vida como esta exigiria "a insurreição, [...] ela deve ser, portanto o estado permanente de uma república” (ibid., p. 216). Insurreição que suscita sempre um esforço a mais, um

\footnotetext{
Sobre este aspecto, Terrasse questiona se o panfleto anuncia, de fato, o fim da sociedade. Para responder em seguida: "Apenas para aqueles que confundem a sociedade com o que chamamos de Estado de direito, e especialmente com o Estado sem direito. Quando o homem civil se torna o homem natural, a comunidade humana ou mesmo nacional subsiste, mas sujeita à única lei da selva. A destruição do aparato estatal significa que os crimes individuais não sofrem mais consequência; não sendo amplificadas por solidariedades coletivas, as desordens permanecem pontuais. Sade conseguiu encontrar essa lição em Rousseau, para quem as desigualdades dificilmente ameaçam a felicidade dos homens, desde que não sejam institucionalizadas" (1989, p. 50).
} 
esforço que impulsiona continuamente cada homem às atitudes necessárias à sustentação da nova sociedade que se estagna e se enfraquece quando moralizada. Nisto consiste o empenho do verdadeiro republicano que dela toma parte.

Feitos os esclarecimentos e dadas as sugestóes, cuja intenção era a de contribuir para a elaboraçáa do novo código republicano em processo, Sade concluiu que:

Agora que, a respeito de tudo isso, estamos curados da multidáo de erros religiosos que nos cativavam, e que, mais próximos da natureza pela quantidade de preconceitos que acabamos de aniquilar, só escutamos sua voz, estejamos seguros de que, se houvesse crime em alguma coisa, seria antes por resistir às inclinaçóes que a natureza nos inspira do que por combatê-los, pois, persuadidos de que a luxúria é uma consequência dessas inclinaçôes, trata-se muito menos de extinguir em nós esta paixão do que regrar os meios para satisfazê-la em paz (Sade, I795, p. 217).

Para o que as paixôes necessitam da mais ampla liberdade, vale dizer, necessitam de oportunidade. Única condição que dá ocasião ao ímpeto despótico de cada homem, como disse, "a dose de despotismo que a natureza colocou no fundo do seu coração" (ibid., p. I47), e que carece de uma oportunidade de "expansão livre para esses desejos tirânicos que, apesar dele, atormentam-no incessantemente" (ibid., p. I47), até serem totalmente realizados.

Em suma, a condição fundamental é que o libertino disponha de um ambiente que fornece a proteção necessária contra eventuais restriçóes e sançôes externas. Local que permite se manter em movimento incessante, pois neste aspecto trata-se, como indicou Didier (1973), sobretudo de um materialismo de revolta. Revolta e insurreiçáo que devem ocorrer de modo permanente e que é característica e consequência de uma filosofia que visa o esclarecimento, superação e combate do que julga ser obstáculo e retrocesso político. Local que possibilita a liberdade de realização irrestrita das paixóes, onde a imaginação desimpedida permite a cada corpo seu excesso. ${ }^{6}$ Por isso Madame de Saint-Ange convida Eugénie: "Passemos ao meu boudoir, lá estaremos mais à vontade; já avisei aos serviçais, esteja certa de que não seremos interrompidas" (ibid., p. 50).

A Orgia, longe de ser uma prescrição política, o que faria dela uma simples alternativa à monarquia e à República, pode ser pensada como um efeito da naturalização da vida social e neste sentido, ela enquanto cena, mas também enquanto ambiente, ar-

\footnotetext{
${ }^{6}$ Neste aspecto, Sade teria feito, segundo Deprun, uma interpretaçáo conveniente e distorcida de La Mettrie. Isto porque, na verdade, enquanto "médico determinista, La Mettrie constata que certos homens por suas organizaçōes buscam prazeres que inclusive consideram crapulosos e indecentes" (1976, p. 746) devendo, por isto, serem evitados e corrigidos.
} 
quitetura, topografia, mobiliário, decoração, vestuário, culinária e, sobretudo discurso, sustenta teórico e praticamente o livre exercício de todas as inclinaçóes naturais humanas por meio da roteirização da luxúria delas decorrentes. Para isto ela conta com mais do que regras e disciplina. Conta com uma distribuição arquitetônica onde o libertino se entrega a todas as paixóes que necessitam de total isolamento, privacidade e sigilo. Trata-se de locais variados, castelos requintados, amplos, adequadamente mobiliados, bem abastecidos de alimentos e bebidas tonificadoras, além de bem situados geograficamente e espalhados por muitas cidades da Europa, entre os quais, o famoso castelo de Silling de Les I20 journées de Sodome, de 1785.

Visando regrar seu funcionamento, especialmente a relação entre os participantes, Sade idealizou e regrou uma sociedade. Chamou-a Société des amis du crime, cujo estatuto foi publicado na obra Histoire de Juliette ou Les prospérités du vice, de 1797. Estatuto que, sem dúvida, colabora para o esclarecimento de seu posicionamento político. No interior desta sociedade e sob a proteçâo deste estatuto, o libertino, sem ser confundido com um Soberano que estaria acima das leis, teria a oportunidade de atender às suas inclinaçóes sensíveis tanto com o auxílio de um novo dispositivo legal que disciplina suas práticas, como pela construção de um ambiente adequado. Sob seu abrigo os libertinos se reconhecem como estando entre os fortes. Trata-se de um estatuto concebido sob os auspícios de uma razão expurgada de preconceitos e segundo sua própria filosofia que, como já indiquei anteriormente ${ }^{7}$, foi elaborada pela condução às últimas consequências do empirismo moderno e do materialismo de seus contemporâneos.

Para dar consistência a esta afirmação recorro aos dois parágrafos de abertura do estatuto mencionado. No primeiro, Sade esclareceu que o sentido moral atribuído à palavra crime, como qualificação negativa de ações humanas, não se aplicaria em sua sociedade, pois nela os homens viveriam como que acorrentados apenas às leis da natureza e ao que elas prescrevem neste tema. Ponto de vista que expressa sua concepção de política que tem em primeira instância o propósito de resgatar o homem civilizado, naquele momento em vias de compor uma nova sociedade, restaurando seu estado natural, vale dizer, sua condição fundamental de indivíduo de exceção, como bem definiu Hobbes. Em síntese, Sade visou o regramento de sua sociedade com apelo à escuta da voz da natureza, restaurando seu determinismo.

Para esclarecimento deste propósito, é sempre bom lembrar que, para Sade, o estado social não se distingue, mas se confunde com o natural. Náo apresenta descontinuidade a ser superada, uma vez que o primeiro se prolonga dentro do segundo. Foi apoiado neste ponto de vista que assumiu a tarefa de resgatá-lo para a verdadeira República. Resgate que exige sempre um esforço a mais para sua execução; passos dados sob a forma de insurreição permanente. Assim, seu estatuto denuncia toda forma de lei e de moralismo que se opóe ao determinismo natural, ao

7 No artigo Le Marquis de Sade: un matérialisme aux conséquences ultimes, 2014. 
jogo de forças ao qual pertencem todas as inclinaçóes e desejos delas decorrentes. Estes, na contramão de Rousseau ${ }^{8}$, não foram concebidos por Sade como degeneração da vida em sociedade. Na verdade, como lembra Terrasse, "esta redução da natureza à pura necessidade levanta todo obstáculo à exploração dos instintos e permite reconstruir o estado original do homem, que para dizer a verdade, ele jamais deixou" (Terrasse, 1989, p. 45).

Dando continuidade à noção de Orgia, ilustrativa de sua filosofia, acrescento alguns dados biográficos de Sade me valendo da obra de Donald Thomas, de 1992. Ela revelou uma curiosa fantasia infantil, a "de construçáo de um mundo autossuficiente" (Thomas, I992, p. II7), que teria sido construída a partir das frequentes viagens de inverno aos castelos de familiares. Já adulto, em I774, aos 34 anos, Sade foi acusado de ter levado adiante sua realização tendo como cenário o famoso castelo de Lacoste, na Itália. Experiência que foi sabotada pela fuga de moças insubordinadas e greve de cozinheiras rebeladas, seguido de um processo judicial que o incomodou por anos. Como se vê, não foram apenas as declaraçóes políticas que o levaram aos tribunais e às prisóes. O resultado disto é que o acúmulo de experiências fracassadas, diz seu biógrafo, o colocou diante da alternativa da literatura e do teatro.

Ele ainda informa que foi também em uma viagem à Itália, em I755, que Sade despertou para o reconhecimento do egoísmo como a primeira lei da natureza, dando os primeiros passos em direção à lenta elaboração de sua filosofia materialista. Nesta mesma viagem ampliou seu imaginário e incendiou suas fantasias ao conhecer a Vênus de Ticiano, o museu de cera de dissecação de corpos e a estátua de Hermafrodite. Em Roma conheceu ainda a catedral de Sáo Pedro que, mais tarde, serviu de cenário para as aventuras de Juliette (onde solicitou ao Papa Urbano IV a famosa dissertação sobre o mal e o crime). Finalmente, foi em Florença que teve a oportunidade de identificar a prostituição como a segunda lei da natureza. Ambas foram resumidas em uma lei fundamental da natureza, la raison du plus fort, fundamental sobretudo para a construção de sua filosofia política.

Mais tarde, em I778, acusado duplamente por um espancamento e uma tentativa de envenenamento foi encarcerado em Paris no castelo de Vincennes por treze anos. Ao perder a esperança de liberdade, nele assumiu a condição de leitor e de escritor voraz e assim construiu um mundo particular dentro da cela, realizando literariamente suas fantasias enquanto, segundo alguns comentadores, lustrava suas obras com pensamentos filosóficos. Sade, me parece, foi mais longe, valendo-se e dialo-

8 Igualmente crítico da distinção e do distanciamento entre sociedade e natureza, mas tomando posição contrária à das filosofias da natureza de sua época, Rousseau, enquanto promeneur solitaire, condição que assumiu em I762, visou, na obra Les rêveries du promeneur solitaire, a recuperaçáo da harmonia entre o homem e a natureza, pois a considerava sem contradição e como manifestaçáo de beleza, harmonia e perfeição. Aproximação justamente como possibilidade de reconstrução da integralidade humana, esperando obter da natureza princípios confiáveis para a renovação tanto do homem, tornado livre pelo florescimento de suas disposições naturais, como da sociedade. 
gando, sobretudo, com a história da filosofia. Enquanto detento tomou conhecimento das obras de incontáveis poetas e filósofos de diferentes períodos e origens como Heráclito, Epicuro, Lucrécio, Marcial, Sêneca, Virgílio, Horácio, Tácito, Luciano, Petrônio, Virgílio, Maquiavel, Espinosa, Hobbes, Newton, Buffon, Montaigne, Helvétius, D’Alembert, Voltaire, Rousseau, Condillac, Montesquieu e especialmente D'Holbach e La Mettrie, nos quais inspirou fundamentalmente sua filosofia natural e moral. É verdade que bem à sua maneira.

Com este cabedal, a partir de 1782 passou a redigir suas teses, por exemplo, em obras como Dialogue entre un prêtre et un moribond, um gênero literário frequente nos círculos da ilustraçáo francesa. Nela apresentou a tese, que tomou emprestada de La Mettrie e D'Holbach, de que a vida deve ser considerada como processo mecânico (na verdade fisiológico) que envolve matéria, movimento e sensibilidade, compondo sua própria noção de homem-máquina. Além desta, assumiu muitas outras teses emprestadas do materialismo como a recusa do dualismo cartesiano, pela qual a vitalidade e a sensibilidade são admitidas como propriedades da matéria; a homogeneidade material e a especiaçáo entre os seres vivos; a consideraçáo do homem como uma organização de fibras e tecidos musculares e o prazer como resultado de seu movimento (fenômeno conhecido pela fisiologia da época como iatromecanicismo, concebida por Boerhaave e von Haller); o acaso, conjugado com determinismo, na constituição dos seres vivos (ecoando o atomismo clássico); assim como a ausência de finalidade da existência humana (com exceção da experiência do prazer). É verdade que de fato sustentou um certo princípio de conservação da vida, mas sem incompatibilizá-la com a possibilidade de sua extinção sobre a Terra, o que inclusive recomendou fortemente. Por fim, como um ideólogo, assumiu um ponto de vista sensualista dando à razáo o estatuto de serva da sensibilidade, pelo pressuposto de que a gênese da primeira decorre da complexidade e funcionamento da segunda.

Também de suma importância em sua filosofia foi a consideração do prazer enquanto paixão fundamental para a organização e atitudes humanas. Se servindo de Condillac, mas especialmente de La Mettrie, mesmo que divergindo deles, considerou o prazer, em sua dimensão orgânica, como resultante de uma irritação, uma agitaçáo mecânica intensa das fibras constitutivas do corpo humano. Concepçáo que Sade ilustrou nas frequentes cenas de titilaçôes, espancamentos e flagelaçóes, visando muito além de uma simples transgressão de padrôes sexuais. Ainda neste âmbito, Sade reconheceu a influência da alimentação e das condiçóes geográficas e climáticas na organização do caráter, reafirmando a continuidade entre a dimensão física e a moral, fortemente sustentada por médicos-filósofos franceses do século XVIII, como o próprio La Mettrie, além de Cabanis, cuja obra principal recebeu o nome de Rapports du physique et du moral (1802/1815). A adoção deste ponto de vista antropológico torna compreensível as frequentes peregrinaçóes de seus personagens libertinos pelo continente europeu visando usufruir da diversidade do clima e da abundância de alimentos tonificadores, fundamentais para o exercício da vida libertina. 
As contribuiçóes de Sade decorreram da radicalização de teses do empirismo e do materialismo francês, especialmente as consequências que extraiu da origem sensorial da razão e do ateísmo, mas sobretudo da moral e do desprezo pela conservação da vida, infrequentes em sua época. ${ }^{9}$ Por conta disso, Sade criticou La Mettrie, além de outros filósofos materialistas, por não terem se dado conta de que só o ateísmo radical, somado ao crime, sustentariam de fato a concepçáo do homem como máquina. Para ele, a ingenuidade destes consistia em atribuírem à natureza humana pressupostos como autonomia da razáo, esclarecimento, progresso moral e social, além da presença de um vigoroso instinto de conservação da vida. Ao contrário, segundo Sade, a condição humana estaria fundada na submissão à sensibilidade e à sua finalidade de gozo ilimitado de prazeres. Ela estaria vinculada à voz da natureza, uma certa natureza exaustiva, um pouco distante da de D'Holbach, de Diderot e, ao mesmo tempo, por antecipação, muito próxima de Carnot-Clausius. ${ }^{10}$

Pois bem, para avançar na compreensão da filosofia e do posicionamento político de Sade, assim como do conceito de Orgia que os ilustra, passo agora a contextualizá-los na tradição filosófica moderna. Como diz Monzani (20II), na modernidade uma nova compreensão do homem foi posta em relevo, justamente porque nela teria ocorrido uma reformulação da própria noção de homem, de sociedade e de natureza em geral. Por tudo isto, parece consensual a ultrapassagem que o projeto filosófico da modernidade promoveu acerca da concepção clássica de homem. Algo possível, entre outras coisas, pela evolução da noção de vida passional humana, cuja primazia foi ocupada pelo amor, por exemplo em Malebranche, seguida pelo desejo, em Hobbes, e ultimada pelo prazer, em Condillac. ${ }^{11}$ Dentre os três, considero que Hobbes deu decisiva contribuição para a criação de condiçóes de possibilidade da emergência da obra de Sade, no século seguinte. Digo isto porque também considero que encontramos na modernidade, mas especialmente em Hobbes, algo que

9 Terrasse reforça este argumento ao esclarecer que, por exemplo, o próprio "Diderot, no entanto, queria preservar o caráter moral da natureza, convencido de que, numa sociedade harmoniosa, o físico e o moral concordavam com o mesmo propósito. Mais radical, d'Holbach, no Sistema da natureza, propôs uma visão cosmológica em que uma fatalidade cega preside ao ciclo de mortes e renascimentos; mas ele ainda supunha que o instinto de conservaçáo levou o homem a buscar sua utilidade em vez da destruiçáo. Trata-se de uma busca possibilitada pelo conhecimento de suas leis, portanto admitindo que a mesma contradição que anima a natureza poderia ser evitada no e pelo homem" (1989, p. 44).

${ }^{10}$ Neste caso me refiro à noção de natureza entrópica que atribui (2016) a Sade em condição embrionária. Digo embrionária porque, de fato, Sade muitas vezes externou uma noçáo de natureza sob a perspectiva da conservaçáo, em acordo com a primeira lei da termodinâmica, o que merece ser aqui considerado. $\mathrm{O}$ fez, por exemplo, em Diálogo entre um padre e um moribundo, quando o moribundo ateu e materialista, debatendo sobre o sentido da morte, certamente inspirado em D'Holbach, interrogou seu oponente: "Náo tenho sob os olhos o exemplo de tudo o que é gerado e regenerado perpetuamente pela natureza? Coisa alguma perece ou se destrói no mundo, meu amigo; hoje homem, amanhă verme, depois de amanhă mosca, não é sempre existir? (200I, p. 27). Neste caso, trata-se de um contexto em que, segundo um ciclo determinado por leis de morte e renascimento, a morte resulta da privaçáo temporária de organizaçáo da matéria, mas que náo a impede de interagir, mudar de forma, corromper-se, segundo um movimento que a impulsiona até o repouso e deste novamente ao movimento.

${ }^{11}$ Sobre os diferentes tratamentos que estas paixōes receberam na modernidade, cf. Monzani, 2011. 
qualifico como uma "descoberta" acerca do homem e de sua natureza. Descoberta relativa à equivocidade do desejo em relação a seus objetos, além do egoísmo e da inapetência para a sociabilidade. Equivocidade dos desejos que fundamentou a situação instável e insegura de guerra de todos contra todos, o que ensejou de fato um projeto político sob a forma de um pacto artificial de sustentação e conservação da vida alcançável no interior da civilização, possibilitada pela auto restrição ao direito natural, este sim de natureza entrópica. Pacto responsável pela ultrapassagem do primitivo estado de natureza de direito para o estado civilizado de lei, no qual o homem finalmente se encontrou em segurança e proteção para a concretização de potencialidades e a realização segura de desejos orientados. Tudo justificado e regido, como admitiu Hobbes no Leviatâ, por um princípio de auto conservação que consiste no que reconheceu como essência do conatus, mas igualmente numa prudência adquirida.

Hobbes e Sade podem ser identificados como pontos nevrálgicos da modernidade. Encontramos neles dois projetos filosóficos que em muito compartilham, mas que também se distinguem, de modo que Sade pode ser considerado, com toda licença solicitada ao leitor, um desdobramento ou, quem sabe, uma radicalizaçáo de Hobbes. O mérito deste ponto de vista é que, ao situá-lo na história da filosofia, recoloca adequadamente o problema acerca do posicionamento político de Sade. Ao situá-los percebemos com clareza que o projeto de Estado de Hobbes e a concepção de Orgia de Sade, se caracterizam por intençôes e finalidades distintas, pois enquanto o primeiro, na condição de organização social e política pactuada, visa a segurança e conservaçáo dos seus membros, o segundo, que também considero uma organização social e política, embora muito mais descritiva do que prescritiva, visa a preparação orientada pela natureza para a aniquilação de seus membros.

Este ponto de vista pode ser reconhecido, por exemplo, em Histoire de Juliette, onde Sade, se distanciando de Hobbes, sustentou que a segurança e a conservação da vida humana só ocorrem em função de ligaçóes e de providências que são obra da fraqueza, da educaçáo e dos preconceitos humanos. Assumindo a posição de porta voz da natureza Sade declarou que:

Farás bem se te conservares e multiplicares, relativamente a ti; se te destróis ou destróis os outros, se puderes mesmo aniquilar usando faculdades inerentes à tua espécie $[\ldots]$ se puderes absorver o império absoluto dos três reinos, farás uma coisa que me há de agradar infinitamente; porque usarei, por minha vez, o mais suave efeito do meu poder, que é criar, renovar os seres. Para de engendrar, destrói tudo quanto existe, pois não incomodarás o que quer que seja à minha marcha (Sade, I979, t. II, p. 474).

Com estas palavras sustentou mais uma vez a tese de que a criação e a destruição, assim como o crime são consequências da verdadeira lógica que indistintamente governa o mundo material (físico e biológico) e, por extensão, deve governar o humano, posto que considerados em continuidade. Trata-se de um argumento que encontra 
complemento também em La nouvelle Justine, onde declarou que nossos gostos são naturais e derivados de nossa organização quando "operam criaçóes assim como destruiçôes [...] Aqui está toda a história do assassinato” (id., I977a, t. I, p. 363).

Aconselha atitudes segundo a recomendação da natureza:

Roube, pilhe, estupre, incendeie, torture, assassine seu pai, sua mãe, seus filhos, cometa sem medo todos os crimes que parecem bons para você; eu gosto de suas infâmias, elas me agradam, estáo de acordo com o que espero de você, e eu quero que assim seja, porque eu vos inspiro [...] (ibid., p. 364).

Para completar adiante:

Aprenda que não há nada em você que não pertença a mim, nada que eu tenha colocado sem um bom motivo; a mais abominável de suas açóes, como a mais virtuosa de outro, sáo apenas maneiras de me servir; eu estimo tanto aquele que destrói como aquele que constrói, todos me servem, embora por diferentes meios. Náo te contenhas, desafie as leis, suas convençóes sociais e os teus deuses; escute a si mesmo, e creia que se há um crime a meus olhos, é o de opor ao que te inspiro, tua resistência ou tuas falácias (ibid., p. 365).

Finalizou reconhecendo que "quanto maior for seu crime, mais terá servido à natureza" (ibid.). De modo que, em síntese, há em Hobbes e em Sade uma concordância, a de que os destinos proporcionados por suas organizaçóes políticas dependem de orientaçóes racionais, de um certo esclarecimento. Contudo, ao cabo, também sobre isto divergem. Esclarecer esta divergência nos auxiliará a compreender o tipo de iluminismo que Sade combateu assim como o que se valeu. Para isto, terei que recorrer novamente à história da filosofia, mais uma vez ao materialismo francês do século XVIII.

Recorro a Condillac, especialmente ao Traité des sensations, de 1754, onde realizou o que mais tarde foi nomeado por Destutt de Tracy de ideologia, a saber, a investigação genética das ideias. Trata-se de uma investigação que pressupóe como dado primário do homem a faculdade sensível por meio da qual circulam as afecçóes que ensejam sensaçôes e, quando transformadas, dáo constituição às faculdades racionais. Um processo que executa a passagem ininterrupta do sensível ao racional; uma aplicação da noçáo moderna de continui in natura.

Para melhor compreendermos o papel concedido à sensibilidade, observemos que para Condillac o que chamamos razão, entendimento, ou ainda, faculdade intelectual nada mais é do que uma consequência das experiências sensíveis, que tem como seu primeiro produto a sensação e o último o julgamento.A razáo, justamente enquanto produto da sensibilidade, no exercício de sua função e em decorrência da sua própria experiência, se destaca e opera com autonomia em relação aos apelos da sensibilidade, à toda sorte de inclinaçóes viciosas que dela derivam, opondo-lhe resistência. Deste ponto de vista, Condillac, assim como Hobbes, La Mettrie, D’Holbach, Kant e tantos outros filósofos modernos, concebeu o homem como disposto 
à superação de sua organização natural, quer dizer, de superação de sua imersão inicial na existência sensível por meio de uma razão esclarecida, neste caso, independente da sensibilidade. ${ }^{12}$ Inclusive com o auxílio de um mecanismo biológico de conservação que induz à fuga da dor e à busca do prazer. Trata-se de um homem que dispóe de julgamentos que distinguem, na relaçáo com os objetos do mundo, o que é benéfico do que é prejudicial à sua organização, de modo a orientar seu desejo pelo primeiro e sua aversão pelo segundo. Trata-se de um tipo de princípio de vida, de auto conservação e de harmonia possível com o mundo, presente em toda filosofia moderna, ou quase toda, náo fosse por Sade.

Sade recusa-o, pois tal princípio e uma razão que por ele se orienta atua como agente regulador das inclinaçôes da sensibilidade, administra seus desejos e aversóes e assim suas relaçóes com os próximos e com o mundo. A partir desta gestão da sensibilidade o homem tem a possibilidade de viver o presente tendo em vista o futuro, e ainda, de viver sua própria vida tendo em vista aquele que reconhece como seu semelhante, ultrapassando seu isolamento e auto referência. Prospeccionando o futuro, superando os conflitos de interesse, o homem racional se provê em sociedade de segurança e de autonomia em relação à voz autoritária da natureza. Pode-se dizer que nesta expectativa se comportou a ilustração francesa.

Quanto a Sade, as coisas se passaram diferente. Seus leitores sabem que ele recorreu à mesma genética das faculdades racionais pela via da experiência sensível, contudo extraiu consequências bem diversas das de Hobbes, Condillac, La Mettrie e D'Holbach ao conferir-lhes função e finalidade diversa. Quero dizer, acompanhando-os até certo ponto, mas divergindo, Sade sustentou que toda faculdade racional, uma vez derivada da sensibilidade, deveria permanecer a ela associada, mais do que isso, a seu serviço, atuando segundo a finalidade de atender às suas inclinaçóes e interesses. ${ }^{13}$ Assim, recusou o funcionamento de uma faculdade racional, seja em seu aspecto cognitivo, moral ou estético, que não tenha por finalidade participar do jogo mecânico de forças cegas naturais, reconectando o homem ao seio e ao domínio da natureza, à escuta de sua voz nunca lhe opondo resistência.

Uma de suas consequências inevitáveis foi a sustentação da renúncia à pretensão da liberdade, da autonomia da vontade, como corolário da ausência de oposição entre razão e sensibilidade, entre a ordem natural e a cultural. Renúncia de suma importância para a construção da apatia, vale dizer, uma desubjetivação que Sade concebeu para o libertino, condição de sua admissão à Orgia, à sua sociedade. Nestes

\footnotetext{
${ }^{12}$ Sobre esta possibilidade, Markovits esclarece que segundo La Mettrie, "a organização, enquanto excelente fábrica, pode se modificar pela educação e ganhar propriedades que não dispunha em si. Educação e organização se compóem na máquina humana. A educação humana pode mesmo se afastar da existência animal [...] produzindo seus signos e suas normas" (2006, p. 84).

${ }^{13}$ Sobre esta diferença de ponto de vista, Terrasse lembra que "os filósofos das Luzes inventaram a sensibilidade para obscurecer, ante o abismo que eles abriram, a ausência de um guard rail. O sentimento interior, a "voz da consciência" ressuscitam os valores perdidos. Sade retém apenas a sensibilidade física, a imaginação que faz crescer nossa capacidade de gozar" (1989, p. 47).
} 
termos, fica evidente que sua filosofia moral não admite a hipótese de uma orientação racional da sensibilidade enquanto constrangimento interno e nem mesmo externo, como recomendou Hobbes, Kant etc. Menos ainda admite o reconhecimento de um Direito civil sustentado por instituiçóes reguladoras, vale dizer, conservadoras da vida social. Mais ainda, se houvesse para ele uma lei que fundamente a ação humana, deveria ser a que ordena o pronto e irrestrito atendimento de toda inclinação, a despeito de todo risco de vida.

Este ponto de vista, presente em toda sua obra com maior ou menor ênfase, foi exemplarmente apresentado em La nouvelle Justine. Já em sua introdução, para efeito de epígrafe, declarou que "somos criminosos para ilustrar as inclinaçóes bizarras que nos inspira a natureza” (Sade, 1978, t. I, p. 353). Por este argumento justificou a opção pelo mal e pelo vício, dadas as vantagens que os acompanham. $\mathrm{Na}$ mesma obra, nas palavras do personagem Clément, Sade acrescentou que "a coisa mais ridícula do mundo, minha querida Justine, é querer contestar as inclinaçôes dos homens, contrariá-las, censurá-las ou puni-las, quando elas não estáo conforme, seja às leis do país que se habita, seja às convençóes sociais” (ibid.). Para continuar: "Os homens jamais compreenderão que toda inclinação, que se possa supor bizarra e criminosa, seja resultado de um tipo de organização que nós recebemos da natureza" (ibid.). Dito isto, sempre considerando a singularidade da organização humana, interrogou:

Qual o objeto de gozo do homem? Náo é aquele que dá aos seus sentidos toda irritação a que são suscetíveis a fim de alcançar melhor e mais calorosamente a última crise/convulsão? [...] crise/convulsão preciosa que caracteriza a fruição do bom e do mau, em razão de maior ou menor atividade envolvida nessa crise/convulsão? (Sade, 1978, t. I, p. 358)

Com isto não deixa nenhuma dúvida sobre a regência da natureza e sobre a submissão a ela. Mais ainda, indica a verdadeira função da razão, particularmente de sua faculdade imaginativa, em relação à sensibilidade, considerando que a cooperaçáo entre elas teria como resultado um efeito potencializador da sensibilidade. Descreveu-o nestes termos:

A emoção da voluptuosidade é, sobre nossa alma, uma espécie de vibração produzida por meio das agitaçóes que a imaginaçáo, inflamada pela recordação de um objeto lúbrico, faz experimentar nossos sentidos, ou melhor ainda, pela excitação que nos reapresenta tal objeto de modo que nos abala mais fortemente (ibid., p. 360).

De modo que a voluptuosidade consiste no mais elevado estado "de felicidade física que (o homem) possa alcançar" (ibid., p. 36I), justamente produzida pela intensificação de uma sensação pela via da imaginação. Como se vê, já que não o cria (posto que é de natureza orgânica, como ensinou La Mettrie em Anti-Sénèque), a 
imaginação só atua em favor da intensificação do prazer. Assim, se ceder voluntariamente às inclinaçóes corresponde a obedecer às leis naturais, resistir equivale a ultrajá-las. Nisto reside a contribuição de Sade para a compreensão da natureza humana, a saber, o ponto de vista de que cabe à sensibilidade indicar a própria máxima de nossa vontade e de nossas açóes. Como consequência disto, à maneira do mal radical kantiano, à razão cabe acolher e viabilizar a execução de sua máxima. Lembro que esta possibilidade foi também indicada por Hobbes no Leviatã como sendo um dos fundamentos da guerra de todos contra todos que tem sua causa na diversidade, na espontaneidade dos gostos e no Direito natural a tudo recorrer para seu atendimento.

Sade seguiu denunciando que apenas os moralistas, sejam monarquistas ou republicanos, sustentam que os vícios e os crimes desagradam à natureza e a Deus. Justamente por ignorarem que, de fato, é dela que vem toda ordem de vícios e crimes. Pergunta seu personagem Dubois:

Há uma única de nossas sensaçôes que não provenha dela, um único desejo que não seja sua obra? Seria, pois, razoável dizer que ela nos deixaria ou nos daria inclinações para uma coisa que lhe prejudicasse, ou que lhe fosse inútil. $\mathrm{Se}$, pois, os vícios lhes servem, por que deveríamos querer resistir-lhes? (Sade, I978, t. I, p. 796).

Argumento que faz da razão e da imaginação mestres de obras da sensibilidade, da inclinação e de seus desejos, legítimos guias e reitores de nossas vidas e relaçôes sociais. Sensibilidade e razão coerentes com a natureza, por conseguinte, com a promoção do prazer exaustivo e da felicidade libertina.

Ainda longe de considerar ter alcançado o sentido preciso de seu ponto de vista político, parto para as consideraçóes finais na esperança de pelo menos ter recolocado adequadamente o problema da relaçáo problemática de Sade com a filosofia e a política de seu tempo. Problema, ou enigma que ganha outro contorno se considerarmos que Sade completou um "movimento" cujo início situei no empirismo de Hobbes e que teve seu ápice no materialismo de La Mettrie, D’Holbach, Condillac, entre outros, conduzido às últimas consequências. Sade o fez, ao menos embrionariamente, a partir de uma concepção de natureza com acento entrópico a despeito de seus argumentos em favor da conservação da vida. Em suma, foi pela indicação da presença precoce de noções entrópicas na composição de sua filosofia que sustentei a recolocação do problema da posição política de Sade. Assim, foi apoiado na concepção de natureza exaustiva e de homem a ela identificado, que Sade promoveu a ultrapassagem da noção de cidadão para a de libertino como ser de exceção e de morte, o que de certa forma, permite admitir que ele teria restaurado uma finalidade já abandonada pelos materialistas. 
Foi assim que em lugar do súdito e do cidadão, Sade concebeu o libertino como dotado de um corpo e de uma sensibilidade cuja finalidade é a satisfação plena de toda inclinação. Dotado de um corpo que é palco de conflito, de diversidade e de desordem de paixôes e de desejos que são sempre de morte, cuja realização visa sem hesitar. De modo que da política à felicidade libertina Sade não admitiu descontinuidade nem contradiçáo. Ponto de vista que ficou explícito em Histoire de Juliette, onde proclamou, como vimos, a submissáo à voz da natureza que recomenda que façamos aos outros tudo o que recusamos em relaçáo a nós. Uma recomendaçáo expressa como lei imperativa da razão naturalizada que realiza a determinação destrutiva da natureza. É neste sentido que a Orgia visa, num propósito inverso ao do Estado de Hobbes, à oportunização do convívio efêmero de indivíduos atomizados, verdadeiros seres de exceção, destituídos de qualquer instinto, bom senso, prudência ou princípio de conservação que evite a contradição e o fatalismo da ordem natural. Pela ausência de qualquer laço provedor, Terrasse reconhece que "à exemplo de Rousseau, Sade imagina que nascemos todos isolados" (Terrasse, 1989, p. 45), mas diferente dele, admitiu que nunca deixamos de ser, continua, "todos inimigos uns dos outros, todos em um estado de guerra perpétua e recíproca” (ibid.). Até porque, finaliza, "a obra de Sade tende a suprimir a distinçáo entre estado de natureza e a Sociedade" (ibid., p. 46).

Tudo isto concebido no rico ambiente filosófico que pertenceu. Sobre isto, me coloco em acordo com Terrasse, para quem "Sade não tem nada a esconder ele diz tudo; ele pilha e copia seus antecessores, inspiradores e adversários sempre cúmplices, para forçá-los a confessar o que dizem e, na sua própria voz, proferir o indizível" (ibid., p. 42). ${ }^{14}$ No entanto, o faz sempre mostrando rigor argumentativo e coerência filosófica. Rigor e coerência que me permitiram reconhecê-lo como um representante do materialismo francês, mas ao qual náo se deteve ao revelar a morte como a verdade do materialismo e a exaustão como um objetivo político, que para ser executado exige encore un effort. Desta forma, Sade teria ido muito além do que declara Noëlle Châtelet quando afirma que "Sade não faz nada mais do que tomar as teses materialistas ao pé da letra, ao menos em seus princípios, a fim de justificar [...] o imoralismo de seu próprio pensamento" (Châtelet, 1972, p. 22). Muito além também da proposição de um regime "de anarquia apaixonada" (Roger, 1976, p. 170), como sugere Philipe Roger.

\section{Referências bibliográficas}

BoCCA, F. V. (20I4). "Le Marquis de Sade: un matérialisme aux conséquences ultimes". In: Revista Natureza Humana, vol. I6.

\footnotetext{
14 "Sade n'a rien à cacher, il dit tout ; il pille et copie ses devanciers, inspirateurs et adversaires toujours complices, pour les forcer à avouer ce qu'ils disent et, de sa propre voix, proférer l'innommable” (Terrasse, 1989, p. 42).
} 
BocCA, F. V. (20I6). Do Estado à Orgia. Ensaio sobre o fim do mundo. Curitiba: Ed. CRV.

Cabanis, P. J. G. (1956). "Rapports du physique et du moral”. In: Euvres Philosophiques de Cabanis. Paris: PUF.

CASTRO, C. C. (20I7). "Sade e o conceito de organizaçáo". In: Caderno de resumos do I congresso da ABES XVIII - USP.

ChÂTEleT, N. (1972). (Ed.). Sade. Système de l'agression. Textes politiques et philosophiques. Paris: Aubier-Montaigne.

DidiER, B. (I973). “Sade aujourd'hui”. In: Sade. Justine ou les Malheurs de la Vertu. Paris: Librairie Générale Française.

Dupran, J. (1976). "La Mettrie et l'immoralisme sadien”. In: Annales de Bretagne et des pays de l'Ouest. Tome 83, n. 4. La Bretagne littéraire au XVIII siècle. pp. 745-750.

Condillac, E. B. (1984). Traité des sensations. Paris: Librairie Artheme Fayard.

D'HolBACH, B. (1994). Système social, ou, Principes naturels de la morale et de la politique, avec un examen de l'influence du gouvernement sur les mours. Paris: Fayard.

Hobbes, T. (2003). Leviatã. Tradução de E. Ostrensky. São Paulo: Martins Fontes.

MARILHAT, C. (1997). Un matérialisme radical. Paris: PUF.

MARKOVITS, F. (2006). Et al. (Ed.). "La Mettrie et le thème de l'histoire naturelle de l'homme", In: Matérialistes français du XVIII siècle: La Mettrie, Helvétius, d'Holbach. S. Audidière, Paris: PUF.

Mettrie, J. O. (2004a). Traité de l'Âme, In: Euvres philosophiques. Paris: Coda.

MetTrie, J. O. (2004b). L'homme machine, In: OEuvres philosophiques. Paris: Coda.

MetTrie, J. O. (2004c). Anti-Sénèque, ou discours sur le bonheur, In: Euvres philosophiques. Paris: Coda.

MonZANi, L. R. (20II). Desejo e prazer na idade moderna. Curitiba: Editora Champagnat.

Roger, P. (1976). Sade. La Philosophie dans le pressoir. Paris: Bernard Grasset.

SADE, M. (1782). Dialogue entre un prêtre et un moribond. Bibliotheque Virtuelle. Numérisation rtf: Thierry Selva.

SADE, M. (200I). Diálogo entre um padre e um moribundo. Tradução de L. A. Borges. São Paulo: Iluminuras.

SADE, M. (1785). Les I20 journées de Sodome. Diffusion Libre. Numérisation rtf: J. Franval.

SADE, M. (1996). Sade contre l'Etre Suprême. Paris: Editions Gallimard.

SADE, M. (1976). La philosophie dans le boudoir. Paris: Éditions Gallimard.

SADE, M. (1978). La nouvelle Justine ou Les malheurs de la vertu. Tome I-II. Paris: Union générale d'éditions. 
SADE, M. (I979). Histoire de Juliette ou Les prospérités du vice. Tome I-II-III. Paris: Union générale d'éditions.

SCHOPENHAUER, A. (20I6). O mundo como vontade e como representaçáo. Tomo I. Tradução de E. R. da Fonseca. Curitiba: Ed. UfPR.

SOllers, P. (1996). Sade dans le temps. Paris: Editions Gallimard.

TERRASSE, J. (I989). “Sade ou les infortunes des Lumières”. In: Études françaises 2523 , pp. 4I-52.

Thomas, D. (1992). Marquês de Sade, ofilósofo libertino. Rio de Janeiro: Civilizaçáo Brasileira. 